des mere et spørgsmål om, hvordan dette univers indrettes, eller hvad der konstituerer det, frem for tidligere, hvor det var et spørgsmål om, hvordan det skulle forstås, epistemologisk (se f.eks Brian McHale: Postmodernist Fiction, New York 1987). Dermed bliver det klarere, at Svend Åge Madsen stadig kan forfægte synsvinkel- og attituderelativismen, den sprogspilsorienterede virkelighed, være anti-metafysisk og dekonstruerende og samtidig benytte gamle litterære skabeloner (fortællingen), forfægte kærlighedsforestillingen, naturen, de suveræne livsytringer, udvise politisk korrekthed mv. Pointen er, at Svend Åge Madsens forfatterskab flytter fokus fra en opfattelse af teksten som mimetisk i forhold til virkelighed og ideologi (eller kritik heraf: ideologikritik) til en opfattelse, hvor teksten indforstået spiller på læserens bevidsthed om dens fiktionalitet (dekonstruktiv læsepraksis).

Det er alt dette Anker Gemzøe ikke følger til dørs i forhold til det stilistiske og relationen mellem sprog og virkelighed (realismebegrebet), fordi han konsekvent undgår at deltage i postmodernismediskussionen. I og for sig et sympatisk træk, fordi denne diskussion, specielt i 80'erne var meget modepræget og sløret af upræcis og diffus begrebsdannelse, og som det i sig selv kan tage megen tid at orientere sig i og kræve megen plads at fremstille nogenlunde klart. En anden grund kan være, at Anker Gemzøe faktisk ikke beskæftiger sig med de romaner, hvor denne problematik bliver uomgængelig - med At fortalle menneskene og Syv aldres galskab som de vigtigste. Men det kan jo nå at komme endnu...

\section{Ib Johansen}

\section{På sporet af en flerstemmig poetik}

Henk van der Liet: Kontrapunkter. En studie i Poul Vads skonlitterare forfatterskab, Odense 1997 (Odense Universitetsforlag) .

Inden for de sidste femogtyve-tredive år har den sovjetiske/russiske litteraturforsker Mikhail Bakhtins arbejder spillet en stigende rolle i den vestlige verden; gennembruddet for Bakhtin - og mere specielt for hans karnevals-teori og hans synspunkter omkring det dialogiske og den polyfone roman - var især knyttet til de kulturelle brydninger der fandt sted i Frankrig i slutningen af tresserne, hvor i dette tilfælde Tel Quel-gruppens teoretiske bestræbelser og (i videre forstand) de akademiske stridigheder imellem traditionalister på den ene side og forskellige afarter af strukturalismen og poststrukturalismen på den anden satte den forsknings- og kulturpolitiske dagsorden (jf. også studenteroprørets motto: fantasien til magten). I Skandinavien var der forholdsvis tidligt, d.v.s. allerede i halvfjerdserne, en vis interesse for Bakhtins kritiske forfatterskab; i Danmark manifesterede den sig f.eks. hos Anker Gemzøe og Peter Madsen, i Norge hos Kjartan Fløgstad (jf. f.eks. sidstnævntes Tordenvejen. Kunst og karneval. Essays om popularkunst \& kulturindustri, Modtryk, 1982). På den anden side kan man ikke sige, at disse teoretiske bestræbelser spillede nogen dominerende rolle i det akademiske liv. I firserne og (især) i halvfemserne er Bakhtins 
betydning for den akademiske forskning i Danmark blevet markant øget, hvad man f.eks. kan se i studier som Ole Sylvests Det litterare karneval. Den groteske realisme i nyere danske romaner (Odense Universitetsforlag, 1987), Jens Aage Doctors disputats Shakespeares karneval (Aarhus Universitetsforlag, 1994), Gitte Moses Den endeløse historie - en undersøgelse af det fantastiske $i$ udvalgte danske - svenske - norske romaner efter 1978 (Odense Universitetsforlag, 1996) og endelig i Anker Gemzøes monumentale disputats Metamorfoser i Mellemtiden. Studier i Svend Åge Madsens forfatterskab 1962-1986 (Medusa, 1997).

Den hollandske litteraturforsker og skandinavist Henk van der Liets disputats Kontrapunkter. En studie i Poul Vads skønlitterare forfatterskab (forsvaret ved Rijksuniversiteit Groningen d. 9. oktober 1997) er indskrevet i denne bakhtinianske forskningstradition på dansk (skandinavisk) grund, men Kontrapunkter føjer samtidig nogle afgørende nye elementer og/eller topoi til den teoretiske (over)bygning, idet han inddrager dele af Bakhtins teoretiske/filosofiske oeuvre, som hidtil i nogen grad har været underbelyste i dansk/skandinavisk akademisk sammenhæng. Det gælder først og fremmest den brug van der Liet gør af Bakhtins kronotope-begreb, tematiseret (og foldet teoretisk ud) i det store essay "Forms of Time and of the Chronotope in the Novel" (oversat til engelsk i The Dialogic Imagination. Four Essays, University of Texas Press, 1981, pp. 84-258). Fra samme samling (The Dialogic Imagination) stammer ligeledes essayet "Discourse in the Novel" (pp. 259-422), som Henk van der Liet anfører som en eksplicit inspirati- onskilde i sin Vad-læsning (Kontrapunkter, p. 83).

Henk van der Liets disputats er - som dens ophavsmand selv gør opmærksom på det i sin indledning (p. 12) - udformet som en klassisk forfatterskabsmonografi; i den sammenhæng er det dog vigtigt at understrege, at mere eksplicitte biografiske referencer og overvejelser spiller en minimal rolle i afhandlingen. For van der Liet er det endvidere af betydning at markere, at han (i sin tekstanalytiske praksis) i nogen grad er veget tilbage for "en for håndfast dyrkelse af metodologiske overvejelser" (jf. p. 13); selv taler han direkte om sin "metodiske eklekticisme" (p. 13). Hans afhandling er bygget kronologisk op, d.v.s. han læser hele Vads skønlitterære forfatterskab i laengdesnit, i og med at han præsenterer læseren for en tekstnær, tematisk og strukturelt fokuseret gennemgang af dennes litterære produktion værk for værk - fra digtsamlingen Den fremmede dag (1956) til Vads foreløbig sidste roman Galskabens karneval (1981).

Af stor interesse for den litterære offentlighed er det meget omfattende materiale til belysning af receptionshistorien (modtagelsen af Vads værker fra debuten til idag), som Henk van der Liet fremlægger i sin disputats (jf. især kapitel 1: "En skønlitterær skæbne", pp. 1780 , men også forskellige supplerende materialer af lignende art i de efterfølgende enkeltanalyser). Af denne meget udførlige gennemgang af modtagelsesprocessen fremgår det, at Poul Vad som forfatter i nogen grad har befundet eller befinder sig i en paradoksal situation, $\mathrm{i}$ og med at han på trods af det forhold at en række af hans værker har været anmeldersukceser alligevel kun i begrænset omfang er slået igennem i den of- 
fentlige bevidsthed, hvor der " $i$ grunden aldrig [opstod] et indtryk af et sammenhængende forfatterskab" (pp. 78-79). Henk van der Liet fremhæver ligeledes, at det ikke er langt fra sandheden "at påstå, at Poul Vad i dag er mere kendt som kunsthistoriker end som litterat" (p. 79, jf. f.eks. Poul Vads store, med rette berømmede monografi Hammersh $\phi i$. Liv og vark, 1988). Henk van der Liets projekt går ud på at rette op på hidtidige kritiske forsømmelser og trække nogle linjer gennem forfatterskabet, der får dets indre sammenhængskraft til at træde tydeligere frem.

I kapitel 2 ("Metodiske rammer", pp. 81-134) fremlægger Henk van der Liet så sine metodiske præmisser, hvor Mikhail Bakhtin - som anført ovenfor - er hovedinspirationskilden, men hvor den hollandske forsker samtidig understreger, at han "har fors $\varnothing$ gt at finde en ligevægt mellem teori og empiri såvel med hensyntagen til Poul Vads litterære som til Bakhtins videnskabelige egenart" (p. 83). Det nye ved van der Liets perspektivering er - som jeg har gjort opmærksom på - den plads han giver den russiske forskers (såkaldte) kronotope-begreb, idet den hollandske forsker læser kronotoperne som "narrative kriser", hvor "Handlingsmæssige vendepunkter og pludselige forandringer i teksten finder sted i faste omgivelser, på steder, hvor det ene rum støder op til det andet, som for eksempel: gange, tærskler, vinduer, dørkarme, men også pladser, gader, landeveje, parker, og så videre" (Kontrapunkter, p. 121). I de efterfølgende tekstlæsninger viser dette begreb sig at være højst anvendeligt i forhold til Poul Vads forfatterskab, hvor stor- og provinsbykronotopen, tærskelkronotopen (cf. hertil Bakhtins kronotope-es- say, The Dialogic Imagination, p. 248), en labyrint-kronotope (jf. omtalen af Kattens anatomi som "en labyrint, der gør læsningen til en labyrintisk oplevelse", Kontrapunkter, p. 343), m.v., kommer til at spille en art ledemotivisk rolle i van der Liets fremstilling - under stadig (samtidig) hensyntagen til andre bakhtinianske centralbegreber såsom karnevallet/det karnevaleske, den groteske krop, flerstemmighed/dialogicitet, o.s.v., o.s.v. Og henimod slutningen af kapitel 2 spidsformulerer van der Liet sin læsestrategi, som indebærer at "jeg navnlig vil opsøge og afdække den sproglige flertydighed, karnevaliseringer, groteske billeder og kronotopiske strukturer, sådan som de gør sig gældende i Poul Vads forfatterskab. Og dermed vil jeg fors $\varnothing$ ge at etablere en række forbindelseslinjer, der gør det muligt at opfatte de enkelte værker som dele af Vads oeuvre" (p. 131, van der Liets fremhævelse).

De efterfølgende læsninger er genstandssensitive, nuancerede og præcise tydningsfors $\varnothing \mathrm{g}$ i forhold til hele perioden fra 1956 til 1981, hvor både litteraturhistoriske, genreteoretiske og kulturkritiske perspektiver trækkes udførligt op og kommer til at indgå i fortolkningen. For den fremtidige forsker rummer disputatsen ikke blot en ganske imponerende informationsmangde, præsenteret i en klar og overskuelig form (jf. også den særdeles detaljerede bibliografi, pp. 393-428), men den åbner tillige for en række nye, værdifulde indsigter vis-àvis denne betydelige danske forfatters produktion, idet den peger på hans samhørighed med såvel som hans kritiske dissens i forhold til sin (efterkrigs)samtid, de kulturelle og litterære hovedstrømninger, o.s.v. De efterfølgende kri- 
tiske forbehold gælder derfor ikke så meget - skjulte eller åbenlyse - litteraturvidenskabelige mangler i Henk van der Liets fremstilling, men skal snarere forstås som nærværende anmelders påpegning af nogle Leerstellen i den kritiske diskurs, hvor der er (eller kan være) brug for et supplerende analytisk-teoretisk arbejde.

Henk van der Liets bakhtinianske forklaringsramme fungerer således tilsyneladende bedst $\mathrm{i}$ forhold til den senere (prosa)del af Vads forfatterskab, d.v.s. romanerne fra og med Rubruk (1972). Kritikeren tager selv nogle afgørende forbehold over for anvendeligheden af den overordnede læsestrategis karakteristiske greb i forbindelse med en fortolkning af Vads (eneste) digtsamling fra 1956, Den fremmede dag; det er dog bemærkelsesværdigt, at disse teoretiske forbehold først fremsættes i det afsluttende kapitel 10 ("Konklusioner") og ikke i forbindelse med selve gennemgangen af samlingen i kapitel 3 ("Den fremmede by", pp. 135-52). I "Konklusioner" henviser Henk van der Liet til Bakhtins (i øvrigt problematiske) afvisning af den poetiske diskurs' (mulige) flerstemmighed i essayet "Discourse in the Novel" (The Dialogic Imagination, p. 297), hvor det om det poetiske formsprog hedder: "The meaning must emerge from language as a single intentional whole: none of its stratification, its speech diversity, to say nothing of its language diversity, may be reflected in any fundamental way in [the poet's] poetic work". Om dette (poetologiske) synspunkt hedder det hos Henk van der Liet: "Jeg billiger Bakhtins vragning af lyrikken, fordi den lyriske diskurs til syvende og sidst hviler på og forudsætter en idé om 'a unitary and singular lan- guage and a unitary, monologically sealed-off utterance" (Kontrapunkter, p. 377, jf. Bakhtin, op. cit., p. 296); formuleringen er på dette sted mildt sagt uheldig, for Bakhtin "vrager" vel ikke lyrikken i og med at han indskriver den i en (udpræget) monologisk diskurstype; men Bakhtins kategoriske fremstilling tager på den anden side heller ikke højde for den modernistiske poesis særlige karakter: et digt som T.S. Eliots "The Waste Land" (1921, 1922) er netop kendetegnet ved sin mangestemmighed, i og med at det digteriske jegs (monologiserende) beherskelsesfors $\varnothing \mathrm{g}$ konstant bliver undermineret af en kakofoni af andre stemmer, der gør det umuligt for samme jeg at satte sig igennem som suveræn overstemme, jf. den anvendte collage-teknik (en lignende bevægelse $i$ retning af en både formsprængende og polyfon udtryksmåde inden for det lyriske medium kan man i Danmark, i hvert fald $i$ et vist omfang, finde hos Ivan Malinovski).

Selv om Henk van der Liet i sin behandling af Den fremmede dag har megen sans for Vads intertekstuelle forbindelser til tidligere og samtidige danske lyrikere (f.eks. Jens August Schade og Paul la Cour), kunne man godt have $\varnothing n-$ sket en mere $u d f$ foldet diskussion af Poul Vads modernistiske poetologi - f.eks. under inddragelse af centrale teoretikere som Hugo Friedrich. Men de bakhtinianske præmisser - der får van der Liet til først og fremmest at fokusere på kropsbilleder og grotesk kropslighed i digtsamlingen - stiller sig øjensynlig i vejen for teoretiseringsbestræbelser $\mathrm{i}$ den retning (?).

Henk van der Liet påviser i sin nærlæsning af romanen De nфjsomme (1960) forbindelseslinjer til eksempelvis 
Sartre og Camus (De nøjsomme bliver til noget i retning af "en 'absurd' roman i Camus' forstand”, p. 180); han retter i den sammenhæng opmærksomheden mod de indbyggede fremmedgørelseseffekter (og på ikke-realistiske parametre), mens den tidlige kritik først og fremmest læste De nфjsomme som en "generationsroman".

I kapitlet om Taber og vinder (kapitel 5, pp. 181-226) bliver de formelle (prosa)modernistiske træk ved romanen fremhævet på en endnu mere markant måde, idet der bl.a. henvises til Rainer Maria Rilkes Pariser-roman Die Aufzeichnungen des Malte Laurids Brigge (1910). I denne berømte modernistiske precursor-tekst er det moderne subjekts selvafvigelse og principielle følelse af fremmedhed vis-à-vis en overmægtig virkelighed, in casu et uoverskueligt og truende storbyrum, tematiseret med frapperende prægnans, og man kan genkende nogle af de samme fortællestrukturer hos Vad. Samtidig inddrager van der Liet (endnu engang) Sartre og Camus til belysning af romanens verdensvision, men taler også med Bakhtin $\mathrm{i}$ forbindelse med "den borgerlige tilværelses dæmoniske karakter” (p. 210) - i dette tilfælde på baggrund af en beskrivelse af et stormagasin - om "en betydningsmæssig og grotesk kategori-sammenblanding" (p. 211), hvor "Det virker, som om det er kvinderne, både kunderne og ekspeditricerne, der er til salg" (p. 211).

Måske overspiller Henk van der Liet disse bakhtinianske (plot)elementer, men under alle omstændigheder forekommer det i hvert fald undertegnede, at han ikke er kommet tilstrækkelig langt med modernisme-problematikken i romanen, hvor der er nogle påfaldende lighedspunkter med den skrivemåde og den beskrivelsesstil, som der opereres med i den omtrent samtidige franske nouveau roman (repræsenteret af forfattere som Nathalie Sarraute, Alain Robbe-Grillet, Claude Simon og Michel Butor). I sidste kapitel i Taber og vinder antager den omstændelige omverdensregistrering man kender fra le nouveau roman (mest outreret hos Robbe-Grillet) karakter af en veritabel hermeneutisk krise, hvor jegpersonen ikke længere er i stand til at tyde, hvad han ser (han står foran sit eget hus, og kapitlet slutter med, at han i uendelig langsom slow motion bevæger sig henimod gadedøren og tilsidst åbner den, d.v.s. tærskel-kronotopen aktualiseres endnu engang på dette sted - This is not an exit (?)): "Jeg følte at denne facade burde fortælle mig et eller andet vigtigt, som om den ikke blot var en ting der kunne ses og måles, men også et tegn der kunne tydes. Men hvor meget jeg end prøvede at læse i den sagde den mig ikke noget særligt..." (Taber og vinder, Gyldendal, 1967, p. 306). Den stream-ofconsciousness-teknik som benyttes hos Poul Vad, hvor den minutiøse registrering af de fysiske omgivelser er parret med en generel, i.e. en kosmisk oplфsningstendens, finder man imidlertid også hos en forfatter som Claude Simon, eksempelvis i hans grandiose orkestrering af det franske nederlag til tyskerne ved begyndelsen af Anden Verdenskrig i La Route des Flandres (1960, da. Vejen i Flandern, Arena, 1963): “...et tilbagetog eller rettere en katastrofe midt $\mathrm{i}$ denne form for opløsning af alt som om det ikke kun var en hær men hele verden og ikke kun som fysisk virkelighed men også som den forestilling om den, ånden kan nære...var ved at gå op i 
sømmene smuldre, gå i småstykker blive til vand til ingenting..." (p. 14).

Med Rubruk (1972, anden korrigerede udgave 1990) overskrider Poul Vad nogle af de - epistemologiske og retoriske - rammer, som han i sin romankunst indtil da har bevæget sig indenfor (hvor den modernistiske fortolknings- og erkendelseshorisont har haft afgørende betydning for hans konkrete skrivepraksis). Poul Vad har selv i et essay fra halvfemserne benægtet, at han med $R u$ bruk skulle have forfattet en historisk roman ("og slet ikke en dokumentarisk sådan”, "Højtidelig erklæring”, Knudepunkter, Samleren, 1993, p. 110); Henk van der Liet hævder i modstrid med forfatterens ovenfor citerede udtalelse, at "Rubruk er en historisk roman..." (Kontrapunkter, p. 268), men han påpeger også at romanen etablerer en dialog imellem to epoker, i.e. det trettende århundrede hvor plottet udspiller sig på den ene side og forfatterens egen samtid på den anden, og "Romanens historiske spændvidde bliver så at sige synliggjort af og i tekstens polyfoni” (p. 291); hér bliver med andre ord bakhtiniansk begrebsværktøj (endnu engang) anvendt i tekstanalysen. Henk van der Liet sammenligner i sin første omtale af romanen i kapitel 1 med Umberto Ecos (senere udgivne) Rosens navn (ital. 1980), og i den forbindelse kunne man supplerende henvise til samme Ecos berømte Efterskrift til Rosens Navn (1984, da. 1985), hvor forfatteren netop påpeger det dialogiske forhold mellem fortid og nutid og ironisk understreger: "I alle tilfælde er der én ting, som virkelig har moret mig: hver gang en kritiker eller en læser har skrevet eller sagt, at en af mine munke forfalder til tanker, der er for moderne, så drejede det sig i samtlige tilfælde om uforfalskede citater, jeg havde fundet i 1300-talstekster" (Gyldendals Bogklub, 1985, p. 72). Hele gennemgangen af Rubruk er mesterligt og konsekvent gennemført, og det eneste jeg måske kunne savne er en etablering af mere præcise forståelsesrammer (inden for analysens semiotiske system) for begreber som det historiske eller historicitet. I og med at det drejer sig om en gennemreflekteret brug af historien i kunstnerisk øjemed, ville det måske fremfor at tale om en historisk roman snarere være relevant at benytte en term som er blevet introduceret af Linda Hutcheon i hendes epokegørende studie A Poetics of Postmodernism (1988, 1989), hvor hun taler om historiografisk metafiktion og bestemmer denne genre på følgende måde: "By this I mean those well-known and popular novels which are both intensively self-reflexive and yet paradoxically also lay claim to historical events and personages" (Routledge, Reprinted 1989, p. 5). Det kosmopolitiske koncept i Rubruk og den måde, hvorpå øst og vest, kristendom, muhammedanisme og buddhisme, fortid og nutid, brydes og dialogiserer i romanen gør det nærliggende at gruppere Vads roman inden for samme - narrative og metafiktionelle - kategori som romaner som “The French Lieutenant's Woman, Midnight's Children, Ragtime, Legs, G., Famous Last Words" (Hutcheon, p. 5); verdens heterogenitet, fortællingernes globale gennemslagskraft og det narrative begærs uimodståelige impetus - alle disse træk reflekteres som i et troldspejl både i den genre som de ovennævnte romaner repræsenterer, i.e. den historiografiske metafiktion, og i Poul Vads visionære fremstilling af en fransk munks møde med de 
centralasiatiske steppefolk (og med en helt anden kultur) i Rubruk.

Kattens anatomi (1978) er uden tvivl den Vad-roman der hyppigst er blevet gjort til genstand for bakhtinianske fortolkningsfors $\varnothing \mathrm{g}$. Henk van der Liet opsummerer både tidligere forskningsresultater og føjer nye sten til det kritiske bygningsværk med sin meget fyldige gennemgang af dette hovedværk i nyere dansk litteratur (kapitel 8, pp. 293-344), og han understreger i den forbindelse netop kontinuiteten i Poul Vads oeuvre: "Bruddet med Poul Vads forudgående romaner er ikke så radikalt, som det ser ud. Netop labyrinten som forståelsesmæssigt brændpunkt danner en forbindelseslinje til de tidligere værkers tematiske og narrative særpræg. Klaustrofobiske og mikroskopiske virkelighedsbilleder, tærskelsituationer, forvrængning af romanpersonernes tids- og rumerfaringer, karnevaliseringstendenser og det groteske billedsprog er altsammen elementer, som også forekommer i Poul Vads tidligere værker. Det der imidlertid udgør et grundlæggende brud med dem, er den multi-perspektiviske og multi-subjektive indfaldsvinkel, der faktisk betyder, at romanteksten ikke lader sig ordne som én syntagmatisk fortælling, men kun kan forstås som et rigt væv af parataktiske fortællinger" (p. 342). Hvad Henk van der Liet hér spidsformulerer leder jo tanken hen på postmodernisme-diskussioner siden slutningen af halvfjerdserne, hvor der netop lægges vægt på de "store fortællingers" sammenbrud og fremkomsten af nye narrative mikrologier. Men det er another story - som kunne tages op igen i anden sammenhæng.

Poul Vads hidtil sidste roman, Galskabens karneval fra 1981, får derimod en lidt stedmoderlig behandling i Henk van der Liets afhandling. Det er naturligvis rigtigt, at den er en roman af en anden type, dersom man sammenligner dens mere asketiske stil med det formidable narrative overskud i en roman som Kattens anatomi. Det forekommer i den sammenhæng nærliggende at sætte romanen - som ofte simpelthen bliver læst som en nøgleroman - i relation til Bakhtins diskussion af den (antikke) menippaiske satire (jf. hans Dostojevski-bog). En gruppe kunstnere, kunstkendere, museumsfolk, akademikere og kunsthandlere udgør hér det brogede persongalleri, og det er helt klart at Poul Vad ikke har bestræbt sig på at skabe "runde", men tværtimod "flade" karakterer i sit plot (for nu at benytte en gammel distinktion, som stammer fra E.M. Forster). Imellem de (fjorten) karakteristika som Mikhail Bakthin fremhæver som konstitutive for denne klassiske genre er der især to som er relevante i sammenhæng med Galskabens karneval: (1) den menippæiske satires forkærlighed for "skandaløse optrin, ekscentrisk optræden, upassende bemærkninger og adfærd..." (Problems of Dostoevsky's Poetics, Edited and Translated by Caryl Emerson, University of Minnesota Press, Second printing, 1985, p. 117, min oversættelse) og (2) genrens intensive beskæftigelse med samtidige og aktuelle emner (dens "journalistiske" kvaliteter, cf. ibid., pp. 118-19). I Galskabens karneval er der mange eksempler på ekstrem og ekscentrisk opførsel fra personernes side (jf. f.eks. det afsluttende optrin, hvor den anarkistiske kunstner og performance-artist med det "talende navn" Kitschklinger (!) sammen med sine to muser (Willemijn og Sidsel fra Ærøskøbing) invaderer Det 
Mest Moderne Museum med den hensigt at gøre "museet til en sandkasse" (Galskabens karneval, Arena, 1981, p. 183)! På ét plan finder man således i Galskabens karneval et sardonisk (og gennemført satirisk) portræt af dansk kunstliv i halvfjerdserne og fremefter fra hesteslagtning som performance til de seneste års rådnende dyrekroppe, udstoppede hunde og molesterede busser (de sidste happenings havde begribeligvis ikke fundet sted endnu på romanens affattelsestidspunkt, men tendensen, det provokatoriske sigte, er det samme i romanplottet og i det offentlige rum), og under alle omstændigheder kan man "genkende" mange samtidsfænomener og -begivenheder (i forstørret og forvrænget form) i Vads menippæiske satire - hvad der som sagt har ført til at romanen er blevet opfattet som en blot og bar nøgleroman. I stedet for at læse Galskabens karneval på romanens (og genrens) egne præmisser, kritiserer Henk van der Liet den for ikke at være forankret i den grotesk-karnevalistiske tradition ("I Galskabens karneval mangler i vid udstrækning den groteske realismes livgivende dialog mellem den intellektuelle og den kropslige erfaring ...”, p. 369). Men i den menippæiske satire kan det intellektuelle moment godt være kraftigere betonet end i f.eks. den karnevalistiske roman à la Rabelais (ifølge Northrop Frye er et af genrens kendetegn netop en fremstilling af personer-som-talerør-for-idéer, og le personnage régnant er i mange tilfælde en "stortalende filosof" [philosophus gloriosus], cf. Anatomy of Criticism, Atheneum, 1966, p. 309). Galskabens karneval er under alle opstændigheder befolket af den ene criticus gloriosus, artifex gloriosus, mercator gloriosus, etc., efter den anden, og de flade karakterer med deres talende navne bebor et ubestemmeligt, konturløst pandæmonium, hvor intellektuelle diskussioner, polemikker og fejder hele tiden udspiller sig for $\varnothing j$ nene af et måbende publikum.

Efter læsningen af Henk van der Liets både stof- og tankemættede disputats hvor der på en yderst idérig måde åbnes for helt nye perspektiver på et centralt dansk efterkrigstidsforfatterskab - kan man have en fornemmelse af, at der måske især er to problemer/problematikker, som kræver fortsat kritisk refleksion fra (litteratur)forskernes side, forsåvidt angår Poul Vads position i den hjemlige litteratur (det drejer sig hér om principielle problemstillinger): (1) for det første aktualiserer Henk van der Liets disputats spørgsmålet om forholdet mellem en nutidig/nulevende forfatters egen opfattelse af sin produktion på den ene side og på den anden den rolle som kritikken som institution kan komme til at spille i denne sammenhæng; (2) for det andet gør den anlagte bakhtinianske synsvinkel i Kontrapunkter det nødvendigt at reflektere over, hvorledes (og i hvilket omfang) Bakhtins metode(r) overhovedet lader sig bringe i anvendelse på det tyvende århundredes litteratur, for det er naturligvis ingen hemmelighed, at den russiske forskers foretrukne unders $\emptyset$ gelsesobjekt(er) i meget vid udstrækning er aldre - klassisk, men også mere "perifer" - litteratur; i det store kronotope-essay kan man endvidere - som hos György Lukács - spore en negativ eller fjendtlig holdning til centralmodernister som Poe og Baudelaire.

(1) Angående det første punkt kan vi henholde os til den føromtalte Vad-tekst 
“Højtidelig erklæring”, hvor han summarisk om sit forfatterskab erklærer:

De nøjsomme er ikke en generationsroman.

Taber og vinder er ikke en psykologisk udviklingsroman.

Dagen før livet begynder er ikke en roman om unge menneskers udvikling og om livet i en militærnægterlejr.

Rubruk er ikke en historisk roman (og slet ikke en dokumentarisk sådan).

Kattens anatomi er ikke en fantastisk roman.

Galskabens karneval er ikke en nøgleroman.

(Knudepunkter, p. 110).

Og Poul Vad programmatiske erklæring slutter med en blank afvisning af sådanne "dårlige" læsere (herunder øjensynlig en hel række kritikere): "Alle der hævder det modsatte er dårlige læsere, svindlere og bagtalere" (p. 110).

Denne kategoriske be- eller fornægtelsesstrategi i forhold til en række etablerede fortolkningstraditioner minder mest af alt om en generel krigserklæring against interpretation! Henk van der Liet prøver at imødegå erklæringen med hensyn til Rubruk, og på egne vegne (jf. Sfinksens forvandlinger, 1986) må jeg nok afgive dissens med hensyn til Kattens anatomi; forsåvidt der i denne roman er tale om tydelige spor, som peger tilbage i retning af en fantastisk fortællecyklus som Jan Potockis Manuscrit trouvé à Saragosse, skrevet ca. 17971815 - et værk som eksempelvis Tzvetan Todorov citerer igen og igen i sin studie over den fantastiske litteratur forekommer det absurd at benægte tilhørsforholdet til den fantastiske fortælletradition (cf. hertil Kontrapunkter, p. 58 , note 132). Måske er forfattere ikke altid deres egne bedste læsere - og un- der alle omstændigheder må kritikeren have en vis plads at røre sig på inden for det hermeneutiske rum; ellers bliver det næsten umuligt at etablere et genuint $d i$ alogisk forhold imellem tekst og læser (for ikke at tale om en veritabel Gadamersk horisontsammensmeltning).

(2) Med hensyn til modernisme-problematikken er sagen mere kompliceret end som så. Som i Rabelais-bogen optræder moderniseringsprocessen i kronotope-essayet i det store og hele som en forfaldshistorie (cf. til denne problematik mit essay "The Semiotics of Laughter", in: Signs of Change. Premodern/Modern/Postmodern, ed. Stephen Barker, State University of New York Press, 1996, især pp. 7-8 og pp. 12 ff.). Selv taler Bakhtin i kronotope-essayet om den post-Rabelaiske latter som en latter, der bærer vidnesbyrd om "a rupture with the gross realities of life" (The Dialogic Imagination, p. 237). Henk van der Liet fremhæver for sit eget vedkommende "i Bakhtins skrifter en dårlig skjult implicit (under)vurdering af den moderne litteratur og en vis idealisering af fortidens (især klassiske) litterære værker" (p. 129). I den sammenhæng må man naturligvis også betænke, at det kunne være vanskeligt i Stalin-tidens Rusland at fremkomme med positive synspunkter vis-à-vis den vestlige modernistiske poesi og prosa (eller overhovedet at få adgang til den) - man kan i den sammenhæng blot tænke på hvor lang tid det tog at få rehabiliteret Kafkas forfatterskab i Østeuropa efter den Anden Verdenskrig. På trods af den meget begrænsede stillingtagen til det tyvende århundredes litteratur i Bakhtins kritiske forfatterskab har en lang række teoretikere imidlertid fors $\emptyset \mathrm{gt}$ at bringe hans teorier i anvendelse på netop moderne - 
og modernistisk - digtning; hér kan nævnes kritikere som Per Dalgård, Terry Eagleton og Nancy Glazener, som læser henholdsvis Aksjonov, Kundera og Gertrude Stein i lyset af Bakhtin. Henk van der Liets projekt lader sig sammenligne med disse (nyere) teoretiseringsfors $\emptyset \mathrm{g}$. Alligevel forekommer det mig, at hans læsninger ikke helt tager højde for alle de vanskeligheder, der er forbundet med at indsætte Vads tidlige (modernistiske) prosaværker i en bakhtiniansk forklaringsramme; specielt i forbindelse med De nфjsomme og Taber og vinder bliver der nogle kritiske mellemled (eller mellemregninger), som kommer til at mangle. Til gengæld kommer begrebsapparatet til at passe meget bedre på romaner som Rubruk, Kattens anatomi og (i mere begrænset omfang) Galskabens karneval. Hér forekommer det mig især at afhandlingens styrke ligger - og man kunne så måske $\emptyset$ nske sig, at Henk van der Liet på et senere tidspunkt ville følge op med en lidt mere udførlig behandling af Poul Vads essayistiske og kunstkritiske og historiske forfatterskab i firserne og halvfemserne. Hér er der endnu områder at udforske - steder hvor Poul Vads særlige kunstneriske sensibilitet og kølige klarsyn gør sig gældende på en bemærkelsesværdigt prægnant måde. Om ikke andet kastes der jo i disse skrifter lys over Vads alment-æstetiske og poetologiske præmisser - over hans kunstneriske valgslægtskaber og de traditioner han føler en særlig affinitet til. Og dette felt kunne det nok være værd at få profileret lidt skarpere i en fremtidig studie.

\section{Bo Kampmann Walther}

\section{Vi ser på tekster}

Per Krogh Hansen og Jørgen Holmgaard (red.): Billedsprog. Om metaforen og andre troper, Skrifter fra Center for Æstetik og Logik, Aalborg Universitet, vol. 2, København 1997 (Medusa).

Først havde jeg tænkt mig at indlede med følgende formulering og så ellers smøre tykt på: »Sproget er gennemsyret af billeder«. Sætningen skulle, i sin lidet fikse kombination af kitch og sandhed, lægge en føler ud til besværlige emner som lighed, forskel og interaktion, måder, hvorpå metaforen, dette besværlige barn i litteraturens familie, er fors $\emptyset \mathrm{gt}$ forklaret og udviklet - ja til tider undskyldt - gennem tiderne.

Hurtigt fandt jeg ud af, at mit ubehjælpsomme bon mot $\mathrm{i}$ bedste fald blot meddelte, at sproget altid meddeler sig selv: sætningen om billeder, der på én gang udtrykker funktion og ontologi, er selv et billede. Faktisk er billedet (om billedet) hugget fra palimpsesten; som om sproget var et fint netværk af næsten gennemsigtige lag, af original og aftryk, land og kort; en syre, der langsomt, men usvigeligt sikkert, både ødelæggende og åbenbarende, trænger ned i dybden.

Billedsprog. Om metaforen og andre troper er redigeret af Per Krogh Hansen og Jørgen Holmgaard, der også bidrager med hhv. indledning og et essay om førsokratikernes billedopfattelse. Bogen har sit udgangspunkt i et ph.d.-arrangement fra 1996, hvis tema og titel var »Det litterære billedsprog «. Det er dog ikke alle de mundtlige bidrag, der har fundet vej til bogen. Dette skyldes sik- 